p. 55

体青

\section{地城社会におけるスポーツ絸權の成立基盭とその 社会的㧼能}

東北大学大学院 近 藤 忠

今日わが国の多くの町や村では，「健康で明るい町つ くりを」といら共通的なスローガンの下に，スポーツに よる地域社会の組織化ないしは再組織化が進められてい るが，そのような全体的な町づくり計画の中で, 住民の スポーツ活動がどのよらな策件の下に，いかにして組織 化され，それが地域社会の全体系の币でいかなる機能を 果しているかということはきわめて興味ある問題であ る. しかしながら，一般にそれが制度的な基艋をるち， 或る程度基準的な形態を一侓に具体化しらる学校体育や 学生スポーッの組織と異り, 社会体育とりわけ地域住民 のスポーツ組蟣は，それが個々の地域的特徽を反映した 現実的生活条件に直接対応するかぎりに扎いて成立し， それぞれきわめて多様な存在形態を示するのであるがた めに，その構造なり機能なりを分析的に考察するに際し ては，ただ個々の実態的側面を深く堀下げるだけでな く，それをとりまく全体系としての地域社会の環境的諸 条件に対してどのような対応の状況を示しているかとい らことについての全体関連的なフプローチの仕方が要請 されるのである.

地域社会に㧊けるスポーツ組織と環境との関係を一つ の全体系的次元においてみたばあい，操作的には一応つ ぎの二つの㑡面が考えられる，その一つは，舆境的諸条 件-が住民のスポーツ活動を組蟣的方向に規定する側面で あり，むら一つは住民の組蟣的なスポーツ活動が逆に地 域社会の全体系何何かのインパクトを与える反作用の 側面である.

先ず第一の側面についてみれば，それに作用する環境 的諸条件にはいろいろなるのが考兄られる。しかしその すへでは活動の性格や分析視角に応して相対的なむので ありまたその規定性の強さも一様ではない，しかしなが らそれを住民のスポーツ活動の組䋘化といら視点からみ るばあい,一応つぎの二つに類型化しその影裙する局面 を相対的に拾付することが必要である.すなわち一つ は，とりわけ倜人のスボーッ活動に対する欲求なり関心 なりに作用し，活動の具体化組織化への動機的枠組を規 定する主観的偯境条件であり，むら一つは，住民のスボ
一ツ活動に必要な時間，経費，用具施設さらには指薄シ ステムや仲間の存在といつたような活動組織化のための いわば条件整備の面に強く作用する客観的摆境条件で ある. そしてこの両者の规定性の強さにどのような傾斜 がみられるかといらことが，その地域社会に抈けるスポ 一ッ組織の組樴過程を最も強く規定しているように思わ れる。

つぎに住民の組蟣的なスポーツ活動が这に環境的諸米 件に対して働きかける機能的反作用の側面はとりわけ社 会構造との対応関俰においてょり顕著に示される，とく にスポーツ組織といろいろな既存の地域集団や組織との

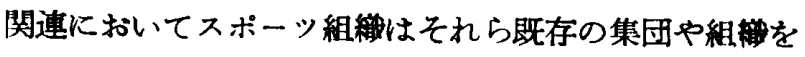
そのサブシステムとして包搨することによつて独自の構 造的機能的側面に深く透し，たとえ一時的にではある にせよ或る程度それを変革せしめることすら可能であ る.またはじめにも述べたように，「スポーッで明るい 町つくりを」といつたスローガンを一つのシンボルとし て，地城住民のスボーツ活動が組蟣化され，それによつ て地域社会の体制面に働きかけるばあいもあるが，しか し，スポーッの組織は本来あくまでも任意的なものであ り，地域住民のすへてををそれにさそい迈むことは理論的 にも，また現実的にも殆んど不可能である．したがつて 概してその構造はメンバーの同質性確定性に依存してお り，それを操作して地域社会の体制的矛盾や対立を解决 する運動にまでその機能を発展させることはきわめてむ つかかしいといわねばならないささらにそれに関連して， 地域住民のスポーツ活動が，スポーッに本質的な非合理 性をその㩊れ䕊とする一部有力者や特定機関の利害の具 に供せられるといらスポーツ組樴の潜在的逆機能にわれ われはとくに注目したいと思ら。

いずれにせよ地域社会に和けるスポーッ組織は以上迈 べてきた二つの側面に括いて地域社会の全体系的な環境 的諸条件に対応しつつその存続発展の過程においてはつ ねにその内部的調整をはかるといらきわめてダイナミッ クな活動のシステムとして理解されるのであり，その分 析にはわが国地域社会の基礎構造に対する十分な社会学 的洞察の下により実践的な方法論的視角が検付されなけ ればならないのである。 